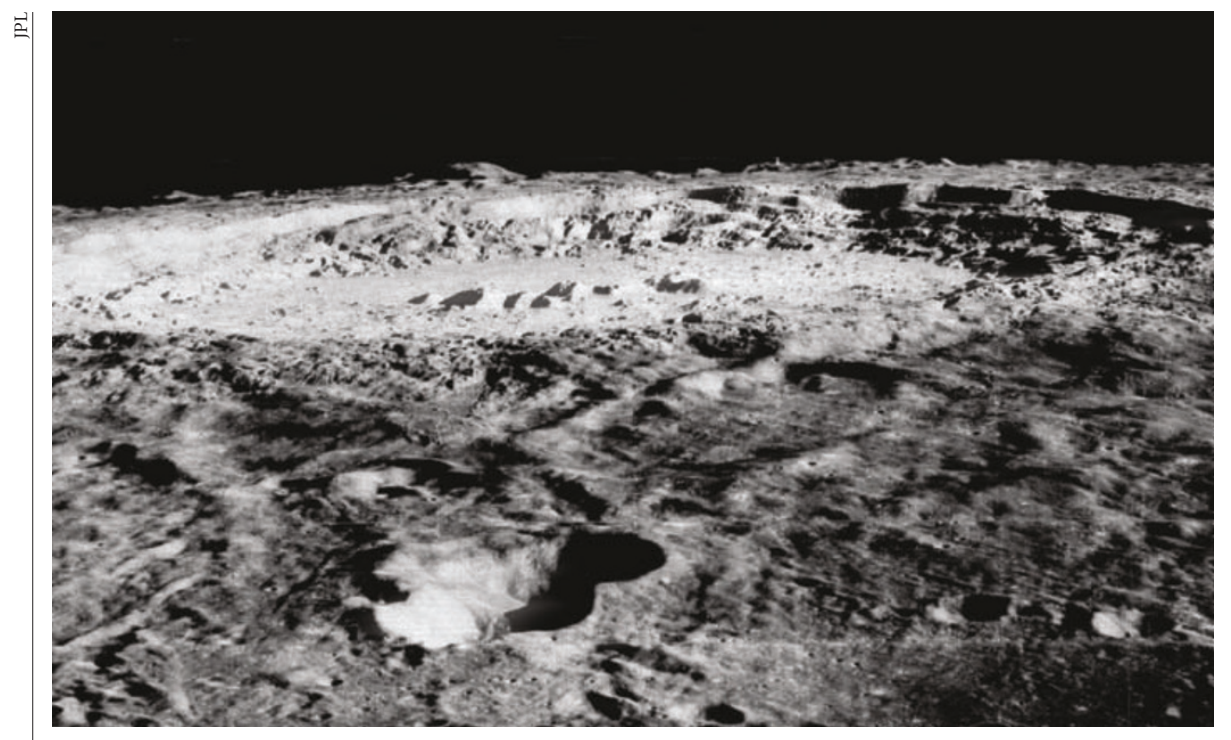

One small step: NASA's push to revisit the Moon's surface starts with a lunar reconnaissance orbiter.

\section{Senator urges private groups to run cut-price Moon shot}

Tony Reichhardt, Washington

A key Senate committee, frustrated with what it claims are inflated cost estimates at NASA, is calling for the next lunar science mission to be handed to the private sector. But space-agency officials say that letting an outside group run the Lunar Reconnaissance Orbiter mission would be risky and may jeopardize a planned 2008 launch date.

The lunar orbiter is meant to be a first step towards a manned mission to the Moon by 2020, which should in turn pave the way for future trips to Mars. NASA wants the orbiter to create a high-resolution photographic map of the lunar surface, locate mineral deposits and possible water ice from orbit and characterize the threat from radiation to future astronauts.

Even though the Moon is not a new destination, the mission will be challenging, says James Garvin, who heads NASA's lunar science programme. The craft will have to enter into low orbits, carry sophisticated instruments and handle high rates of data flow.

Garvin reckons that the orbiter will cost about as much as a Discovery mission, some $\$ 400$ million. NASA estimates that its entire lunar programme, including the orbiter and early work on subsequent lunar landers, will cost some $\$ 1.3$ billion between 2005 and 2009. The agency wants the orbiter to be built and operated by its Goddard Space Flight Center in Greenbelt, Maryland, with many of the components contracted out.

Senator Sam Brownback (Republican, Kansas), who chairs the authorizing committee that sets policy guidelines for NASA, calls those price tags "way too high". He says it should be possible to do the first lunar mission by 2007 for less than $\$ 200$ million. The 1994 Clementine lunar mission run by the Pentagon, for example, cost about $\$ 80$ million, although much of the technology it used had already been developed.

Brownback has introduced a bill — written in part by adviser Simon 'Pete' Worden, a former US Air Force space official who worked on Clementine — calling for NASA to come up with a new plan for the lunar mission that includes "the use of the private sector to accomplish the goals of the mission".

This could include private companies or non-NASA research groups, such as the Johns Hopkins University Applied Physics Laboratory in Maryland, which has built NASA spacecraft in the past. Splitting the lunar mission into several cheaper spacecraft could be one way of bringing costs down.

Echoing a recent presidential-commission report (see Nature 429, 793; 2004), Brownback says "we're not going to get to the Moon and Mars" unless NASA changes its way of conducting space missions. Leaving it to outside engineers and scientists to work out how to accomplish NASA's broad goals should help to kickstart a more diversified space industry, he adds.

But Garvin says that given the tough requirements and tight schedule, the safest course is for Goddard to build this first lunar spacecraft itself. Three years is generally considered barely enough time to mount a space mission, he says.

The debate should be settled over the next few months as the House of Representatives writes its own authorizing bill and the appropriations committees that set NASA's 2005 budget weigh in.

\section{Watchdog slams failings of Israeli animal-rights law}

Haim Watzman, Jerusalem

Procedures designed to supervise animal experiments in Israel have not been properly implemented, says the government's main watchdog.

In a strongly worded report released on 29 June, the state comptroller said that processes written into a 1994 law to govern animal experimentation have never come into effect.

The National Regulatory Council on Animal Trials, which was set up in 1994 to establish rules for experiments on animals and to oversee them in universities and other research labs, has not operated in full accordance with the law, the report says.

The animal-welfare law states that scientists should only use animals in experiments if they can demonstrate that no alternatives are available. It says they should restrict the number of animals used to a minimum and never make laboratory animals suffer unnecessarily. "In practice, the issue of alternatives has not advanced much during the council's tenure," the report finds.

The National Committee to Approve Animal Experiments, which the council established to apply the law, has not functioned since its last chairman resigned two years ago, the report says. Since then, individual institutions have established internal review committees to oversee their experiments, as the law permits. But the comptroller says that these committees have not represented non-biologists, as the law requires.

Ehud Ziv, a physician at the Hebrew University of Jerusalem's Medical School who became chair of the council on 1 July, says he welcomes the comptroller's report. He disputes the idea that the council has had no effect, however, citing a continuing decline in the number of animals used in individual experiments. In 2002, some 290,000 animals were used in experiments at 48 institutions in the country, according to figures collected by the council.

Some biologists sought to play down the comptroller's criticisms. "It's a standard report," says Alex Tsafriri, a biologist at the Weizmann Institute of Science in Rehovot. Tsafriri is chairman of the Interuniversity Forum for Medical Sciences in Israel, a body set up by Israeli universities to defend the use of animals in science. "It's not surprising to find some creases in the implementation of a ten-year-old law." 